\title{
Factors Affecting Bromus tectorum Seed Bank Carryover in Western Utah
}

\author{
Duane C. Smith, ${ }^{1}$ Susan E. Meyer, ${ }^{2}$ and V. J. Anderson ${ }^{3}$ \\ Authors are ${ }^{1}$ Research Associate and ${ }^{3}$ Chair, Department of Plant and Wildlife Sciences, Brigham Young University, Provo, UT 84602, USA; and \\ ${ }^{2}$ Research Ecologist, USDA Forest Service, Rocky Mountain Research Station, Shrub Sciences Laboratory, Provo, UT 84606, USA.
}

\begin{abstract}
Cheatgrass (Bromus tectorum L.) is a winter annual weed that presents a serious obstacle to rangeland restoration in the Intermountain West. The objective of this study was to evaluate factors regulating the size and persistence of cheatgrass carryover seed banks on semiarid sites in western Utah. We prevented current-year seed production in each of four habitats, then tallied emerging seedlings over the next 4 yr. Two iterations of the study were conducted during consecutive years. One year before initiation of each iteration, we estimated seed rain at each site. Above-average precipitation in 1998-1999 resulted in relatively high seed rain (13942 seeds $\left.\cdot \mathrm{m}^{-2}\right)$ for the first iteration, whereas seed rain for the second iteration averaged only $3567 \cdot \mathrm{m}^{-2}$ because of drought conditions in 1999-2000. Mean total number of seedlings emerging from carryover seeds for the first and second iterations were 1304 and 270 seedlings $\cdot \mathrm{m}^{-2}$. Seedling emergence from carryover seed was positively correlated with production-year seed rain $\left(R^{2}=0.69\right)$. The fraction of seed rain that carried over tended to be lower when precipitation the year following production favored fall emergence of the transient seed bank. First-year emergence of carryover seeds averaged $96 \%$ of total emergence, whereas third-year emergence averaged $<1 \%$ and was zero for six of eight cases. Carryover seeds persisted somewhat longer at the xeric black greasewood site than at more upland sites. Our study shows that cheatgrass seeds rarely persist beyond the second carryover year even on semiarid sites. Emergence from the carryover seed bank can be predicted from site attributes and precipitation patterns in previous years.
\end{abstract}

\section{Resumen}

La espiguilla colgante (Bromus tectorum L.) es una pasto invernal que presenta un serio obstáculo en la restauración de los pastizales en el oeste inter montano. El objetivo de este estudio fue evaluar los factores que regulan el tamaño y la persistencia del banco de reserva de semillas de la espiguilla colgante en los sitios semiáridos en el oeste de Utah. Nosotros evitamos la producción de semillas del corriente año en cada uno de los quatro hábitats, y luego los juveniles que crecieron en los próximos 4 años. Las dos iteraciones del estudio fueron llevadas a cabo durante años consecutivos. Nosotros estimamos la lluvia de semillas en cada sitio un año previo al inicio de cada iteración. La precipitación sobre el promedio en el 1998 al 1999 resultó en una lluvia de semilla relativamente alta $\left(13942 \mathrm{semillas} \cdot \mathrm{m}^{-2}\right)$ para la primera interacción mientras que la lluvia de semilla para la segunda iteración promedio solo 3567 semillas $\cdot \mathrm{m}^{-2}$ debido a las condiciones secas en el 1999 al 2000 . La media del número total de juveniles emergentes de las semillas de reserva para la primera y segunda de las iteraciones lo fue 1304 y 270 juveniles $\cdot \mathrm{m}^{-2}$. El juvenil emergente de las semillas de reserva fue correlacionado positivamente con la producción anual de lluvia de semillas $\left(R^{2}=0.69\right)$. La fracción de la lluvia de semillas que se reservó tendió a hacer más baja cuando la precipitación al año siguiente a la producción favoreció el emergente de otoño del banco transitorio de semillas. La emergencia del primer año de de la reserva de semillas promedio un $96 \%$ del total emergente, mientras el emergente del tercer año promedio $<1 \%$ y fue cero para seis de ocho casos. Las semillas de reserva persistieron un tanto más en los sitios de "xeric black greasewood" que en muchos sitios montañosos. Nuestro estudio muestra que las semillas de espiguilla colgante rara vez persisten más allá del segundo año de reserva incluso en sitios semiáridos. La emergencia del banco de reserva de semillas puede ser predecido a partir de los atributos del sitio y los patrones de precipitación en años anteriores.

Key Words: cheatgrass, downy brome, secondary dormancy, seed rain, seedling emergence, semiarid

\section{INTRODUCTION}

Cheatgrass or downy brome (Bromus tectorum L.), an exotic winter annual grass, which has achieved dominance on tens of millions of hectares in the Intermountain Western United States, presents a major obstacle to rangeland restoration (Monsen 1994; Booth et al. 2003). It begins growth earlier in the spring than most native perennials, depletes soil moisture, and is a prolific seed producer. As an annual plant, cheatgrass depends

Research was funded by the US Dept of Defense and Brigham Young University.

Correspondence: Duane C. Smith, Dept of Plant and Wildlife Sciences, Brigham Young University, Provo, UT 84602, USA. Email: mrdcsmith88@gmail.com

Manuscript received 14 April 2007; manuscript accepted 21 April 2008. on seeds to perpetuate itself and to persist on a site. These seeds may either germinate within the year following production, i.e., from the transient seed bank, or they may carry over to subsequent years as a persistent seed bank. Once cheatgrass plants have emerged, they can be controlled by various measures, but potential plants that exist as ungerminated seeds in the seed bank are difficult to control. They can cause excessive competition when they emerge later with seeded species (Evans 1961; Monsen 1994). For this reason, it is important to know the size of the carryover seed bank, so that appropriate management prescriptions can be written and implemented.

In spite of the apparent importance of the seed bank in mediating cheatgrass abundance and persistence, there are remarkably few studies on seed bank dynamics of this species 
Table 1. Habitat attributes and fire history for four study sites on the US Army Dugway Proving Ground, Tooele County, Utah, where emergence from cheatgrass carryover seed banks was followed.

\begin{tabular}{lcccc}
\hline Potential vegetation & Elevation $(\mathrm{m})$ & Aspect/slope & Fire history & Soil attributes \\
\hline Black greasewood & 1329 & Nil & 1998 & Very deep, fine, sandy loam \\
Black sagebrush & 1579 & NW $5-15 \%$ & 1998 & Very deep, very cobbly loam \\
Big sagebrush & 1554 & Nil & 1995 & Very deep, gravelly loam \\
Utah juniper & 1670 & NE 15\% & 1994 or 1995 & Very deep, very cobbly loam \\
\hline
\end{tabular}

(Chepil 1946; Hulbert 1955; Young et al. 1969; Hull and Hansen 1974; Wicks 1997; Meyer et al. 2007). These studies reported carryover values from first-year seed banks from $0 \%$ to $30 \%$. They used a variety of techniques, including greenhouse emergence bioassays, in situ seed bank sampling, and seed packet retrievals. Only two studies (Chepil 1946; Hulbert 1955) have examined seed bank persistence in situ by quantifying seedling emergence over time. These studies, both conducted in more mesic environments outside the area where cheatgrass poses a serious problem in wildlands, concluded that naturally dispersed seeds of cheatgrass do not persist beyond $1 \mathrm{yr}$.

Extensive investigation has shown that cheatgrass seeds are dormant at dispersal and lose this dormancy through dry afterripening under summer conditions, so that in fall they are completely nondormant and poised to germinate very quickly (Allen and Meyer 2002; Roundy et al. 2007). If the seeds do not remain hydrated long enough to complete autumn germination, they may enter secondary dormancy under winter conditions (Young et al. 1969; Evans and Young 1975). This enables them to avoid germination the following spring and therefore to carry over. Not all ungerminated seeds enter secondary dormancy; some are capable of spring emergence. Seeds in second dormancy lose the dormancy through dry after-ripening over the subsequent summer, in the same manner as recently dispersed seeds, and are again ready to germinate the following autumn (Beckstead et al. 2007).

In the study reported here, we followed carryover seed-bank depletion at four cheatgrass-infested semiarid sites in western Utah by preventing seed rain, then quantifying seedling emergence in subsequent years. Our primary objectives were 1) to determine the pattern of seedling emergence from the carryover seed bank following prevention of seed input, and 2) to quantify factors that affect the size and persistence of the carryover seed bank. We expected that temporal variation in precipitation would play a role in determining the size of the carryover seed bank as well as the pattern of depletion. We also expected that patterns of seedling emergence and seed bank carryover would vary as a function of habitat. And, because all cheatgrass seeds are nondormant in fall, whether they are current-year or carryover seeds, we predicted that most carryover seeds would germinate the first year, with exponentially decreasing numbers from year to year and very small numbers beyond 3 yr postproduction.

\section{METHODS}

\section{Study Sites}

The study area is located in Tooele County, Utah, on the US Army Dugway Proving Ground. We selected sites representa- tive of four community types throughout the Great Basin that are undergoing conversion to cheatgrass monocultures. The sites were arrayed along a shallow topographic gradient and were dominated by the following species: 1) black greasewood (Sarcobatus vermiculatus Hook.), 2) black sagebrush (Artemisia nova A. Nels.), 3) big sagebrush (A. tridentata Nutt.), and 4) Utah juniper (Juniperus osteosperma Torr.; Table 1). Wildfires occurred at all sites during the 1990s, shifting community dominance from perennial woody vegetation to cheatgrass. Data from the nearby Dugway, Utah, National Oceanic and Atmospheric Administration reporting station (mean annual precipitation $199 \mathrm{~mm}$ ) were used as an indicator of year-toyear variation in the amount and seasonality of precipitation during the study (Western Regional Climate Center 2007). Average distance from study sites to the Dugway reporting station was $16 \mathrm{~km}$.

\section{Field Experiments}

The experiments were carried out twice in time at each study site. The first iteration was initiated after prevention of currentyear seed dispersal in summer 2000 and quantified emergence from carryover seeds produced in 1999 and before. The second iteration was initiated in summer of the following year (2001) and quantified emergence from seeds produced in 2000 and before.

Three replicates per iteration were established at each site for measuring carryover seedling emergence. To exclude windblown cheatgrass seeds, a fine aluminum screen, $46 \mathrm{~cm}$ high, was erected around circular plots measuring $2 \mathrm{~m}$ in diameter. The current-year seed crop within each plot was prevented from dispersing by clipping and removing cheatgrass plants before seed maturity. Subsequent emergence data were taken from a circular subplot, $1 \mathrm{~m}$ in diameter, within the larger plot, or from two randomly selected quadrants within the 1-m circle located in the center of the plot. Any emerging seedlings in the subplot were removed and tallied. Care was taken to ensure that coleoptile, seed, and a portion of the radicle were removed. Soil disturbance was kept to a minimum by using fine-pointed forceps to remove seedlings by grasping them by the root. Russian thistle (Salsola kali L.) plants were removed to prevent shading of the plots and to facilitate seedling removal. The perimeter, or buffer plot, was maintained free of cheatgrass by clipping or plucking plants.

Plots were regularly checked for emergence, and observations were made any time emerged seedlings were present from fall through spring during both iterations. Emerged seedlings were observed on 12 sampling occasions from 14 September 2000 through 5 May 2003. After 5 May 2003, the plots were monitored for emergence until May 2004, but no further emergence was observed. 
Contamination by extraneous seed was theoretically possible because the tops of the screen exclosures were open. However, Hulbert (1955) found that cheatgrass seeds were usually dispersed less than $1 \mathrm{~m}$ and that they were much more likely to move along the surface than to be transported through the air. Throughout our study period, cheatgrass outside the plots did not exceed the height of the plot exclosures, making seed contamination an unlikely source of significant error.

Seed production (seed rain) was estimated at each site in 2000 and at sites comparable to three of the four sites in 1999. The point-centered quarter method was first used to determine plant density (Bonham 1989). Twenty points were sampled per area. For each plant in each quarter, the number of culms per plant and number of spikelets per culm were counted, and mean number of fertile florets in randomly selected spikelets was also determined. Seed production was determined by multiplying plants $\cdot \mathrm{m}^{-2} \times$ culms $\cdot$ plant ${ }^{-1} \times$ spikelets $\cdot$ culm $^{-1} \times$ fertile florets $\cdot$ spikelet $^{-1}$. In 2000, transects for estimating seed production were located at each site near the seed-bank study exclosures. Seed production estimates for 1999 were obtained for comparable salt-desert shrubland, black sagebrush, and big sagebrush sites and were incidental to other studies. No seed production estimate was available for the Utah juniper site in 1999.

\section{Statistical Analysis}

Results of the emergence experiment were formally analyzed using mixed-model analysis of variance (Proc Mixed, SAS Version 8; Littell et al. 1996) for a repeated-measures design. Iteration and site were treated as fixed main-plot effects, whereas year was treated as a fixed subplot effect because measurements were repeated in time on the same plots (repeated measures). Plot nested within site and iteration was the random variable. Seedling counts were summed for each plot across the emergence dates within each year to obtain a yearly emergence total. To balance the design for analysis, only $3 \mathrm{yr}$ were included for the first iteration. As mentioned above, there was no emergence in the fourth year. Seedling count (density) data were log-transformed to improve normality before analysis.

Total mean carryover seedling emergence for each iteration and site was related to seed rain using simple linear regression with seed rain as the regressor variable (Quinn and Keough 2002). This analysis included only seven of eight points because no seed-rain estimate was available for the first iteration at the juniper site. We also examined within-year trends in emergence patterns for each iteration and site and related these to yearly precipitation and habitat differences. These patterns were examined graphically.

\section{RESULTS}

\section{Field Experimental Treatment Effects}

Carryover year showed a highly significant effect on seedling emergence averaged across sites and iterations $(F=108.93$; $\mathrm{df}=2,48 ; P<0.0001)$. In support of our hypothesis that emergence from the carryover seed bank would decrease exponentially through time, a mean of $96 \%$ of the carryover seeds emerged during the first carryover year, 3.6\% emerged during the second carryover year, and $0.4 \%$ emerged during the third carryover year. In six of eight cases, there was no emergence in the third carryover year (Fig. 1).

Total mean carryover seedling emergence summed across years was nearly five times greater for iteration 1 than for iteration 2 (1304 vs. 270 mean total seedlings $\cdot \mathrm{m}^{-2}$ ), and the difference between iterations was highly significant $(F=70.91$; $\mathrm{df}=1,48 ; P<0.0001)$. In spite of similar patterns of exponential decline in the two iterations, the iteration by year interaction was also highly significant $(F=8.74 ; \mathrm{df}=2,48$; $P=0.0006)$. For iteration 1 , the carryover seed bank was $94.7 \%$ depleted by the end of the first year and was $99.3 \%$ depleted by the end of the second year (Fig. 1). For iteration 2, depletion took place somewhat more rapidly, with $97.4 \%$ of the seed bank depleted at the end of the first year and $100 \%$ depleted at the end of the second year.

There were also significant differences among sites in the mean size of the carryover seed bank $(F=4.67$; $\mathrm{df}=3,48$; $P=0.0061)$. Averaged across iterations, the two sagebrush sites had similarly high total mean emergence (973 seedlings $\cdot \mathrm{m}^{-2}$ for the big sagebrush site and 941 seedlings $\cdot \mathrm{m}^{-2}$ for the black sagebrush site). The other two sites had similar lower values for total mean emergence, averaging about twothirds of the seedling numbers for the sagebrush sites (651 seedlings $\cdot \mathrm{m}^{-2}$ for the juniper site and 582 seedlings $\cdot \mathrm{m}^{-2}$ for the greasewood site).

Even though patterns of seed-bank depletion across years appeared quite similar among sites within each iteration, there was a significant site by iteration by year interaction in the analysis $(F=4.29$; df $=6,48 ; P=0.0015)$. This was largely because carryover seeds tended to persist somewhat longer at the xeric greasewood site than at the three more upland sites (Fig. 1). Iteration was involved in the interaction because the year that generated this increased persistence at the greasewood site, namely the drought year of 2001-2002, occurred in the second carryover year for iteration 1 , but in the first carryover year for iteration 2 (Fig. 1).

\section{Relationships With Seed Rain and Precipitation Patterns}

Based on our seed production estimates, relatively large numbers of seeds were added to the average iteration 1 seed bank in 1999 (mean of 13942 seeds $\cdot \mathrm{m}^{-2}$ ), whereas input to the seed bank in 2000 for iteration 2 was estimated to be much lower (mean of $3567 \mathrm{seeds} \cdot \mathrm{m}^{-2}$ ). This explains in large part the fivefold difference in carryover seedling emergence between the two iterations. Total carryover seedling emergence $\cdot \mathrm{m}^{-2}$ was significantly related to production year seed rain (seedling emergence $=0.087($ seed rain $)+36.1 ; R^{2}=0.69 ; \mathrm{df}=5$; $P<0.05$; Fig. 2). This relationship explained $69 \%$ of the variance in carryover seedling emergence. The slope of the equation (0.087) provides an approximate measure of the proportion of the seed rain that was likely to carry over at least $1 \mathrm{yr}$ in this study.

This difference in seed production between the two iterations was itself largely explained by between-year variation in precipitation (Fig. 1). For iteration 1, above-average precipitation in both fall 1998 and spring 1999 favored relatively high seed production, whereas for iteration 2 , drought conditions in both fall 1999 and spring 2000 reduced seed production severely (Meyer et al. 2001). The difference between produc- 

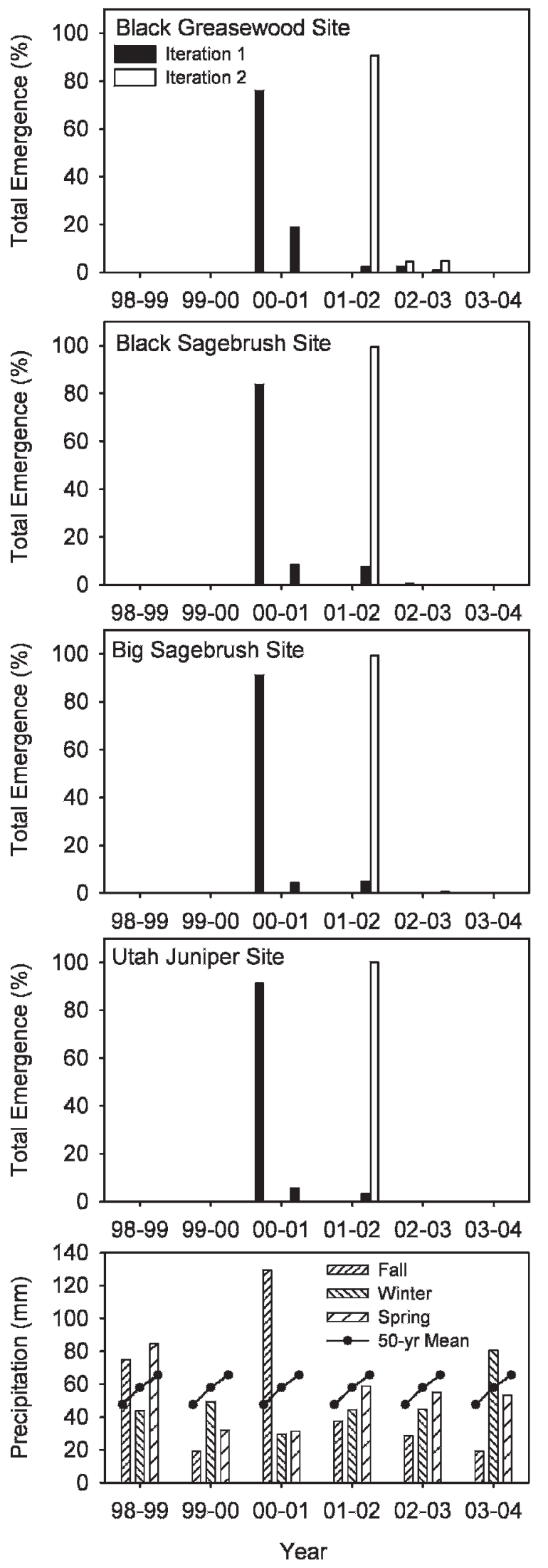

Figure 1. Percentage of total seedling emergence from the carryover seed bank at four sites as a function of season (fall or spring) and year of emergence for two carryover emergence study iterations. For iteration 1 , seeds were produced in 1998-1999 or before, the transient seed bank

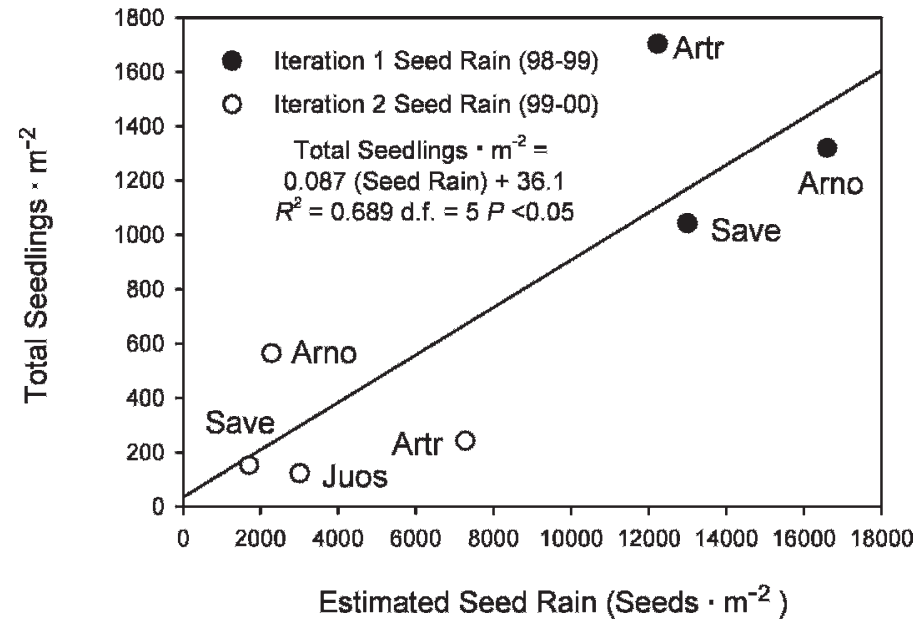

Figure 2. The relationship between estimated production-year cheatgrass seed rain and seedling emergence from the carryover seed bank. Seed-rain estimates were made in the immediate vicinity of the seedling emergence plots for iteration 2, whereas for iteration 1, seed-rain estimates came from comparable sites in the area. There was no seed-rain estimate available for the Utah juniper site for iteration 1. Points are labeled with a four-letter code based on the Latin name of the former dominant species at each site: Artr indicates big sagebrush site; Arno, black sagebrush site; Juos, Utah juniper site: Save, black greasewood site.

tion years undoubtedly contributed to the significant correlation between seed rain and carryover seedling emergence (Fig. 2). This result provides support for the hypothesis that carryover seed densities are related to production year seed rain, which is, in turn, related to production year precipitation.

Another factor that could have contributed to higher emergence from the carryover seed bank during iteration 1 was that precipitation during the first year after seed production (1999-2000), when the transient seed bank would be germinating, was low, so that carryover was probably promoted. For iteration 2, precipitation during this first postproduction year (2000-2001) was more favorable, especially in fall. This could have resulted in more complete germination of the transient seed bank and even lower carryover (Fig. 1).

\section{Within-Year Patterns of Emergence}

Within-year carryover seedling-emergence patterns the first year varied substantially both between iterations and among sites (Fig. 3). The biggest difference between iterations was that in iteration 1, most first-year emergence took place in the fall, whereas in iteration 2, there was no autumn emergence at all. This was clearly a result of differences in precipitation patterns (Fig. 1). The first carryover year for iteration 1 was 2000-

germinated in 1999-2000, and the first year for carryover-seedling emergence was 2000-2001. For iteration 2, seeds were produced in 1999-2000 or before, the transient seed bank germinated in 2000-2001, and 2001-2002 was the first year for carryover-seedling emergence. Precipitation totals for fall, winter, and spring each year of the study at Dugway, Utah, are shown in the lower panel along with the longterm means. 

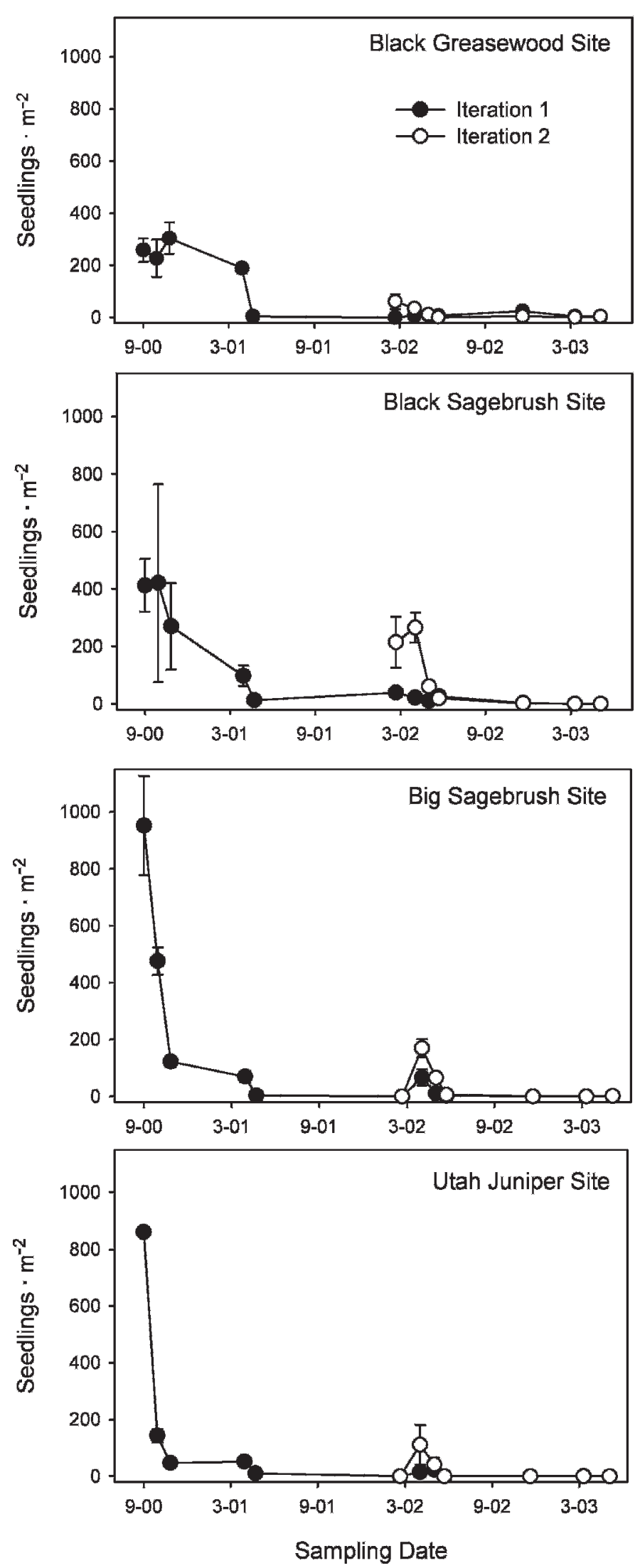

Figure 3. Time courses of carryover-seedling emergence for each of two iterations at four sites from fall 2000 through late spring 2003. Plots were monitored for an additional year at all sites, but no further emergence occurred. Time courses begin for each site and iteration at
2001, a year with exceptionally high autumn precipitation. In contrast, the first carryover year for iteration 2 was 20012002 , a year with a dry autumn. The first effective precipitation arrived in November, in the form of snow that did not melt until late February. Emergence took place in spring, within a few weeks of this snowmelt event.

There were also clear differences among sites in emergence timing patterns (Fig. 3). At the greasewood and black sagebrush sites, autumn emergence for iteration 1 was slow and spread evenly over three sample dates, whereas at the big sagebrush and juniper sites, most emergence had occurred by the first sample date. The sites with slower autumn emergence also had less total emergence and a smaller proportion of total emergence in fall.

Emergence also varied by site during iteration 2, and the patterns were similar to those of iteration 1 (Fig. 3). Emergence the first spring was more prolonged at the black sagebrush and greasewood sites when compared with the big sagebrush and Utah juniper sites. The big sagebrush and Utah juniper sites had no emergence on the February sample date because of persistent snow cover, which probably increased the synchrony of seedling emergence at these sites.

\section{DISCUSSION}

The pattern of carryover seed bank depletion observed in our study supported the predictions of exponential decline in the size of the carryover seed bank through time and relatively short seed-bank longevity. There was some evidence that seeds germinated earlier, more synchronously, and to higher percentages on sites with apparently more favorable soil-moisture relations and in years with more favorable precipitation patterns, but this did not result in major differences in seedbank persistence. The xeric greasewood site had significantly higher carryover after the drought year 2001-2002, but even this site averaged only $3.2 \%$ of total emergence in the third carryover year.

Our study provided evidence that cheatgrass carryover seedling density is positively related to production-year seed rain. The regression slope was 0.087 , indicating that, on average, $8.7 \%$ of the seed rain carried over. Meyer et al. (2007) found a similar significant correlation between early autumn, transient seed-bank density and carryover seed-bank density late the following spring. First-year seed bank carryover at two sites during that 4-yr study averaged $16 \%$ and $9 \%$.

Carryover in our study expressed as a percentage of seed rain averaged $7.6 \%$ under the scenario of high-germination probability of the transient seed bank, i.e., above-average precipitation the autumn following seed production (iteration 1). Under the scenario of little or no autumn germination of the transient seed bank, carryover averaged 9.3\% (iteration 2). This difference between iterations provides some support for the hypothesis that there will be more seed carryover when dry

$\leftarrow$

the beginning of the first season that seedling emergence was observed (i.e., null emergence on earlier dates is not shown). Standard error bars are shown for each measurement. 
fall conditions decrease the probability of germination of the transient seed bank. A similar negative relationship between fall precipitation and carryover percentage is reported in Meyer et al. (2007). Important sources of seed-bank depletion not measured in our study include losses to granivores and pathogens. We did not quantify the proportion of the seed rain that emerged from the transient seed bank because we were concerned with quantifying the fraction that carried over successfully after all first-year losses occurred, including losses both to germination and to predation and disease. The impact of granivory on cheatgrass seed-bank dynamics is not well studied, but we have considerable evidence to indicate that the fungal pathogen Pyrenophora semeniperda can have a major negative impact on cheatgrass seed banks (Beckstead et al. 2007; Meyer et al. 2007). Years and habitats that are optimal for cheatgrass seed bank carryover also tend to be those that are favorable for this pathogen, which preys primarily on secondarily dormant seeds in the spring seed bank. Attack by $P$. semeniperda may be an important factor preventing the carryover of large fractions of cheatgrass seed banks each year. It may also be a primary reason that cheatgrass seed-bank persistence is generally limited to $3 \mathrm{yr}$ or less, even in xeric environments, where the potential for seed carryover is high.

Seed-rain values in our study, even though substantially different between iterations, were at the low end compared with maximum cheatgrass seed-rain values reported in other studies. Early autumn seed-bank densities in Meyer et al. (2007) varied from 8400 to 31750 , whereas seed-rain values as high as 52000 seeds $\cdot \mathrm{m}^{-2}$ have been observed at Dugway Proving Ground. Such seed-rain values can result in very dense stands. Densities as low as $40-50$ seedlings $\cdot \mathrm{m}^{-2}$ can interfere with establishment of desert wheatgrass (Agropyron desertorum [Fisch. ex Link] Schult.) seedings (Evans 1961).

Another question is whether higher production-year seed rain leads to a longer period of persistence for carryover seeds. Two sites in our study showed some seed persistence through the third carryover year in iteration 1, whereas two did not. Within iteration 1, seed-bank carryover into the third year was not positively correlated with total number of carryover seedlings emerging. In iteration 2, no site showed seed persistence beyond the second carryover year. It is true that total carryover seedling emergence was lower for the second iteration, which also had lower seed rain, but this does not seem to be the reason for reduced persistence. The site whose seeds persisted the longest in each iteration was the greasewood site, where total seed carryover densities were lower, and this increased persistence appeared to be related to exceptionally dry conditions at that site in a drought year. This suggests that, although first and second year seed-carryover densities following years of high production will likely be higher than those we observed, there is no evidence that these seeds will persist longer than the seeds in this study.

One difference between conditions during our study and those in unmanipulated cheatgrass seed banks was that our technique of harvesting and removing current-year plants and removing all subsequent plants as seedlings prevented the replacement of litter as it disintegrated. This meant that carryover seeds after the first season were emerging from a mineral-soil seed bed. Whether this would tend to prolong persistence or reduce it is a matter for discussion. Young and
Evans (1975) reported much less cheatgrass emergence from bare interspaces than from beneath shrubs. They indicated that the harsher, faster-drying conditions of the interspaces were more conducive to the induction of secondary dormancy, which could lead to increased persistence. On the other hand, seedsoil contact could be better for seeds on mineral soil than for those suspended in litter. Our observation is that seeds are more likely to escape germination in the transient seed bank and become secondarily dormant if they are in a high-litter environment. Whether the outcome would have been somewhat different if the carryover seeds in our study had become buried by litter in subsequent years is not known. However, buried cheatgrass seeds are almost always more likely to germinate than those on the surface (Young and Evans 1975). This may mean that our measured persistence periods are somewhat longer than those that would be encountered under natural litter conditions.

\section{MANAGEMENT IMPLICATIONS}

The relationships developed in our study can give some idea of the probable size of the cheatgrass carryover seed bank at a particular site. But in the context of a proposed seeding, a direct measure of carryover seed-bank density would often be desirable. Fortunately, it is not difficult to quantify cheatgrass in situ seed banks directly, either as an aid to development and timing of appropriate treatment prescriptions or as a means of evaluating the success of cheatgrass control (see Meyer et al. 2007 for methods).

There are many factors that lead to success or failure of rangeland seeding, but in general, the fate of a well-designed seeding project is determined by the amount of precipitation received and the severity of competition from cheatgrass or other weeds. In some situations, prevention of seed production may be an adequate control measure that permits a seeding to be successful. In these situations, destroying the seed crop with early-season burning or preventing seed production with a post-emergent herbicide may allow seeding success. If a substantial carryover seed bank is suspected or known to be present, use of a selective preemergent herbicide, such as imazapic, can provide residual control while still allowing establishment of desirable species.

\section{ACKNOWLEDGMENTS}

We thank the Dugway Proving Ground Integrated Training Area Management student technicians and staff, employed by Brigham Young University, who assisted with study installation and data collection.

\section{LITERATURE CITED}

Allen, P. S., and S. E. Meyer. 2002. Ecology and ecological genetics of seed dormancy in downy brome. Weed Science 50:241-247.

Beckstead, J., S. E. Meyer, C. J. Molder, and C. Smith. 2007. A race for survival: can Bromus tectorum seeds escape Pyrenophora semeniperda-caused mortality by germinating quickly? Annals of Botany 99:907-914.

Bonham, C. D. 1989. Measurements for terrestrial vegetation. New York, NY, USA: Wiley-Interscience. 338 p. 
Booth, M. J., M. M. Caldwell, and J. M. Stark. 2003. Overlapping resource use in three Great Basin species: implications for community invisibility and vegetation dynamics. Journal of Ecology 91:36-48.

CheplL, W. S. 1946. Germination of weed seeds, I: Iongevity, periodicity of germination, and vitality of seeds in cultivated soil. Scientific Agriculture 26:307-346.

Evans, R. A. 1961. Effects of different densities of downy brome (Bromus tectorum) on growth and survival of crested wheatgrass (Agropyron desertorum) in the greenhouse. Weeds 9:216-223.

Evans, R. A., And J. A. Young. 1975. Enhancing germination of dormant seeds of downy brome. Weed Science 23:354-357.

HuLBERT, L. C. 1955. Ecological studies of Bromus tectorum and other annual bromegrasses. Ecological Monographs 25:181-213.

Hull, A. C., And W. T. Hansen. 1974. Delayed germination of cheatgrass seed. Journal of Range Management 27:366-368.

Littell, R. C., G. A. Milliken, W. W. Stroup, and R. D. Wolfinger. 1996. SAS system for mixed models. Cary, NC, USA: SAS Institute Inc. 633 p.

Meyer, S. E., S. C. Garvin, and J. Beckstead. 2001. Factors mediating cheatgrass invasion of intact salt desert shrubland. In: E. D. McArthur and D. J. Fairbanks [EDS.]. Shrubland ecosystem genetics and biodiversity: proceedings. Ft. Collins, C0, USA: USDA Forest Service Proceedings RMRS-P-21. p. 224-232.
Meyer, S. E., D. Quinney, D. L. Nelson, and J. Weaver. 2007. Impact of the pathogen Pyrenophora semeniperda on Bromus tectorum seed bank dynamics in North American cold deserts. Weed Research 47:54-62.

Monsen, S. B. 1994. The competitive influences of cheatgrass (Bromus tectorum) on site restoration. In: S. B. Monsen and S. G. Kitchen [EDS.]. Proceedingsecology and management of annual rangelands. Ogden, UT, USA: USDA Forest Service Intermountain Research Station General Technical Report INTGTR-313. p. 43-50.

Quinn, G. P., AND M. J. KeOUGh. 2002. Experimental design and data analysis for biologists. Cambridge, United Kingdom: Cambridge University Press. 537 p.

Roundy, B. A., S. P. Hardegree, J. C. Chambers, and A. Whittaker. 2007. Prediction of cheatgrass field germination potential using wet thermal accumulation. Rangeland Ecology and Management 60:613-623.

Western Regional Climate Center. 2007. Utah. Available at: http://www.wrcc.dri.edu/ summary/Climsmut.html. Accessed 28 December 2007.

WICKs, G. A. 1997. Survival of downy brome (Bromus tectorum) seed in four environments. Weed Science 45:225-228.

Young, J. A., and R. A. Evans. 1975. Germinability of seed reserves in a big sagebrush community. Weed Science 23:358-364.

Young, J. A., R. A. Evans, and R. E. Eckert. 1969. Population dynamics of downy brome. Weed Science 17:20-26. 